\title{
Pengaruh upah minimum kabupaten terhadap pengangguran di Kabupaten Bangka tahun 2007-2018
}

\author{
Putri Indah Lestari*1, Rini Luciani Rahayu², \& Ayu Wulandari1 \\ 1 Fakultas Ekonomi, Universitas Bangka Belitung, Indonesia \\ 2Badan Pusat Statisik Kabupaten Bangka, Indonesia
}

\begin{abstract}
Abstrak: Pengangguran di Kabupaten Bangka selama periode 12 tahun terakhir mengalami fluktuatif. Pada tahun 2007 jumlah pengangguran sebesar 6.900 ribu/jiwa, tingkat pengangguran tertinggi tahun 2015 sebesar 12.805 ribu/jiwa, dan pada tahun 2018 mengalami penuruan jumlah pengangguran sebesar 2.670 ribu/jiwa. Upah Minimum Kabupaten Bangka selama periode 12 tahun terakhir meningkat sebesar 257,85\%. Penelitian bertujuan untuk melihat pengaruh dari upah minimum kabupaten terhadap pengangguran di Kabupaten Bangka tahun 2007-2018. Menggunakan data yang didapat dari Badan Statistik Kabupaten Bangka. Analisis data menggunakan regresi sederhana. Jenis data yang digunakan yaitu data sekunder yang merupakan data yang dikumpulkan secara tidak langsung dari pihak ketiga. Jenis penelitian ini adalah deskriptif kuantitatif. Teknik analisis data dalam penelitian ini yang pertama melakukan uji asumsi klasik, ketiga uji kelayakan model, dan analisis regresi linier sederhana. Berdasarkan hasil regresi sederhana menunjukkan bahwa variabel upah tidak berpengaruh secara signifikan terhadap tingkat pengangguran di Kabupaten Bangka dengan nilai signifikan o,814. Upah Minimum Kabupaten tidak berpengaruh terhadap pengangguran di Kabupaten Bangka disebabkan oleh masyarakat yang termasuk dalam angkatan kerja banyak bekerja di bidang informal.
\end{abstract}

Katakunci: upah minimum; pengangguran; Bangka; angkatan kerja

\begin{abstract}
Unemployment in Bangka Regency during the last 12 years failed to fluctuate. In 2007 the number of payments was 6,900 thousand/person, the highest level of payment in 2015 was 12,805 thousand/person, and in 2018 the number of pensions was 2,670 thousand/person. The Minimum Wage for Bangka Regency during the last 12 years increased by $257.85 \%$. Participatory research to see participation from district minimum payments to purchases in Bangka Regency in 2007-2018. Using data obtained from the Bangka Regency Statistics Agency. Data analysis uses simple regression. The type of data used is secondary data which is data collected indirectly from third parties. This type of research is quantitative descriptive. Data analysis techniques in this study were the first to test the assumptions of the classical model, the third test of the feasibility test, and simple linear regression analysis. The Regency Minimum Wage does not agree with the purchase in Bangka Regency which is influenced by the people in the labor force who work mostly in the informal sector.
\end{abstract}

Keywords: minimum wage; unemployment; Bangka; workforce

JEL Classification: J31; E24; C22 


\section{PENDAHULUAN}

Penduduk merupakan sumber daya yang memiliki peran utama dalam melaksanakan pembangunan sekaligus pengguna dan penikmat hasil pembangunan (Hartanto, 2017). Jumlah penduduk Kabupaten Bangka hasil Proyeksi Penduduk pada tahun 2018 sebesar 330.793 jiwa, bertambah 2,00 persen dari tahun 2017 yang jumlah penduduknya sebesar 324.305 jiwa. Jumlah penduduk Kabupaten Bangka usia 15 tahun ke atas atau yang termasuk Penduduk Usia Kerja (PUK) pada tahun 2018 sebanyak 242.954 jiwa (hasil Survei Angkatan Kerja Nasional (SAKERNAS), Agustus 2018). Berdasarkan data Badan Pusat Statistik (BPS) sebesar 64,10 persen dari PUK termasuk dalam penduduk angkatan kerja (bekerja dan/atau mencari kerja) dan sisanya 35,9 persen adalah penduduk bukan angkatan kerja (sekolah, mengurus rumah tangga, lainnya). Grafik jumlah angkatan kerja di Kabupaten Bangka dapat dilihat pada Gambar 1.

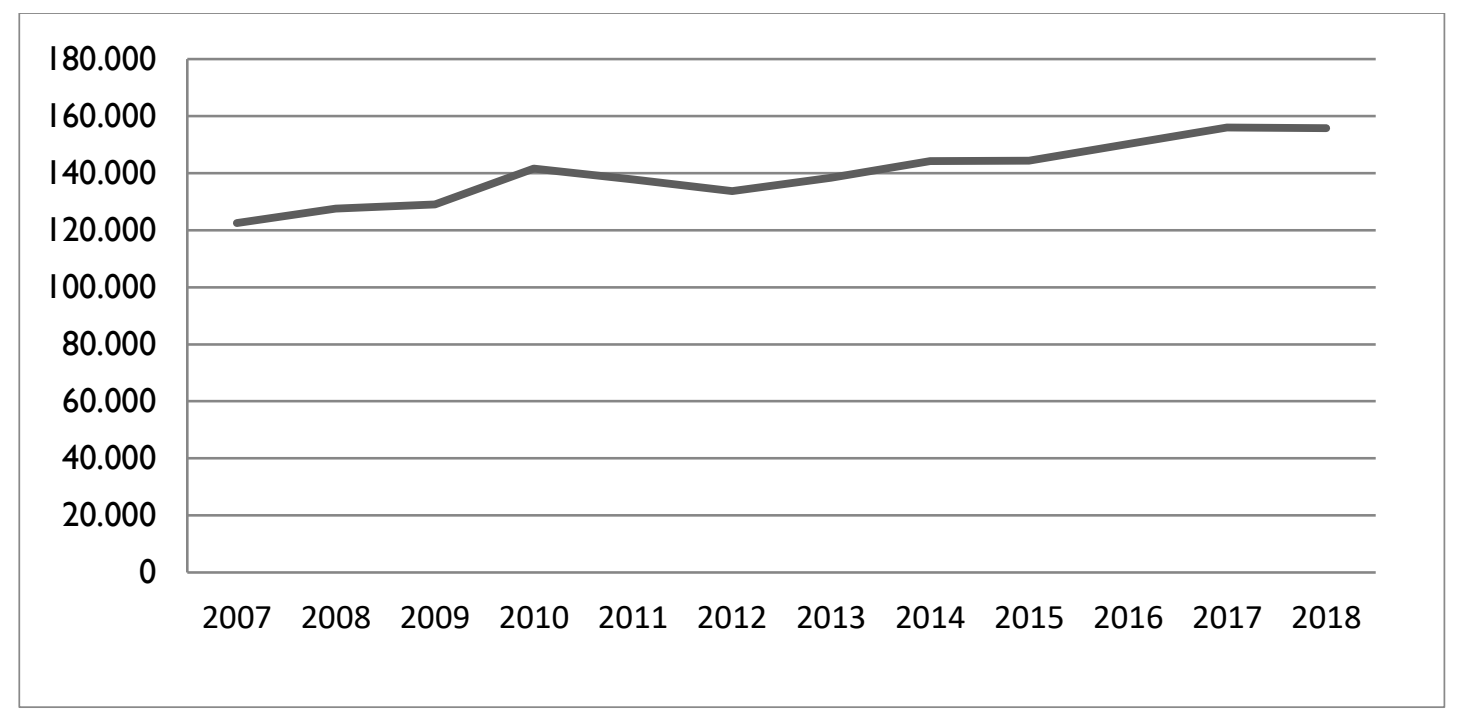

Sumber: Badan Pusat Statistik Kabupaten Bangka, 2019.

Gambar 1. Grafik jumlah angkatan kerja di Kabupaten Bangka 2007-2018

Berdasarkan Grafik 1 menunjukkan bahwa jumlah angkatan kerja Kabupaten Bangka pada tahun 2007 sebesar 122.508 ribu/jiwa dan pada tahun 2018 mengalami peningkatan sebesar 155.733 ribu/jiwa. Peningkatan jumlah angkatan kerja harus diikuti dengan kualitas sumber daya yang baik, jika tidak disertai dengan kemampuan dan usaha dapat menghambat kesempatan kerja dan akan menimbulkan pengangguran (Irewole, 2019; Zulkarnain, 2017).

Menurut Mankiw (2007) pengangguran adalah masalah makroekonomi yang mempengaruhi manusia secara langsung dan merupakan masalah yang paling berat yang akan menyebabkan penurunan standar kehidupan dan tekanan psikologis. Pengangguran adalah suatu keadaan di mana seseorang yang tergolong dalam angkatan kerja ingin mendapatkan pekerjaan tetapi belum dapat memperolehnya (Sukirno, 2006; Iwu \& Opute, 2019). Menurut Badan Pusat Statistik Kabupaten Bangka (2019) pengangguran meliputi penduduk yang sedang mencari pekerjaan, atau mempersiapkan suatu usaha, atau merasa tidak mungkin mendapatkan pekerjaan, atau sudah punya pekerjaan tetapi belum mulai bekerja. 


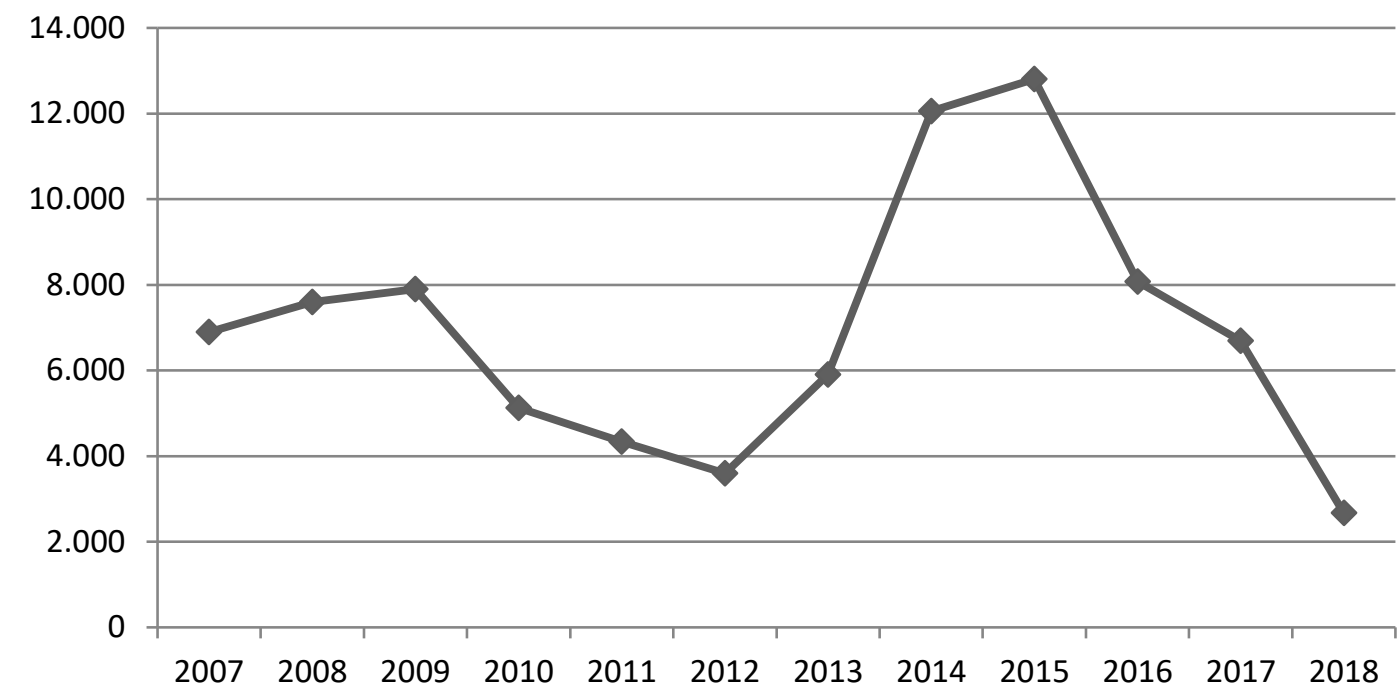

Sumber : Badan Pusat Statistik Kabupaten Bangka, 2019.

Gambar 2. Grafik jumlah pengangguran di Kabupaten Bangka 2007-2018

Pada Gambar 2 dapat dilihat grafik jumlah pengangguran di Kabupaten Bangka selama periode 12 tahun terakhir mengalami fluktuatif. Pada tahun 2007 jumlah pengangguran sebesar 6.900 ribu/jiwa, tingkat pengangguran tertinggi tahun 2015 sebesar 12.805 ribu/jiwa, dan pada tahun 2018 mengalami penurunan jumlah pengangguran sebesar 2.670 ribu/jiwa.

Upah merupakan salah satu faktor yang mempengaruhi tingkat pengangguran (Panjawa \& Soebagiyo, 2014; Sirait \& Marhaeni, 2013). Menurut Mankiw (2007) upah merupakan kompensasi yang diterima oleh satu unit tenaga kerja yang berupa jumlah uang yang dibayarkan kepadanya. Adanya penetapan upah minimum yang dilakukan oleh pemerintah merupakan standar minimum yang digunakan oleh para pengusaha atau pelaku industri untuk memberikan upah kepada pekerja (Nurcholis, 2014).

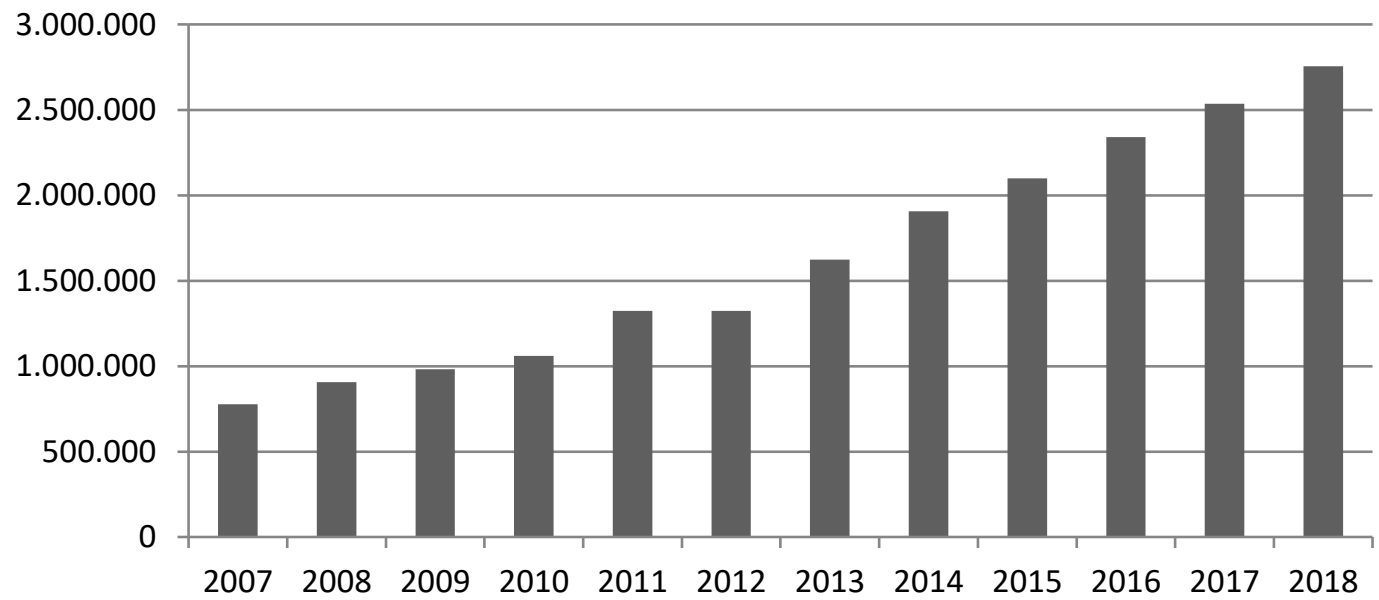

Sumber: Badan Pusat Statistik Kabupaten Bangka, 2019.

Gambar 3. Upah minimum di Kabupaten Bangka 2007-2018 
Berdasarkan Gambar 3 dapat dilihat bahwa terjadi kenaikan upah minimum Kabupaten Bangka selama periode 12 tahun terakhir. Pada tahun 2007 upah minimum Kabupaten Bangka sebesar 770.000 rupiah dan meningkat signifikan sebesar $257,85 \%$ pada tahun 2018 sebesar 2.755 .443 rupiah. Kenaikan upah yang ditetapkan sesuai dengan hasil survei standar kebutuhan hidup layak para pekerja atau buruh untuk dapat hidup layak secara fisik dalam satu bulan. Berdasarkan latar belakang yang telah diuraikan maka peneliti tertarik untuk meneliti pengaruh upah minimum kabupaten terhadap pengangguran di Kabupaten Bangka tahun 20072018.

Penelitian ini untuk mengetahui pengaruh upah minimum kabupaten yang ditetapkan pemerintah terhadap tingkat pengangguran di Kabupaten Bangka tahun 2007-2018. Adapun tujuan dari penelitian ini untuk melihat pengaruh dari upah minimum kabupaten terhadap pengangguran di Kabupaten Bangka tahun 20072018.

\section{METODE}

Penelitian ini menganalisis tentang pengaruh upah minimum kabupaten terhadap pengangguran di Kabupaten Bangka. Variabel independen adalah upah minimum kabupaten dan variabel dependen adalah jumlah pengangguran di Kabupaten Bangka. Penelitian ini meliputi data tahun 2007 sampai 2018 menggunakan data tahunan dengan jenis data sekunder yang merupakan data yang dikumpulkan secara tidak langsung dari pihak ketiga. Jenis penelitian ini adalah deskriptif kuantitatif.

Teknik analisis data dalam penelitian ini yang pertama melakukan uji asumsi klasik yang terdiri dari uji normalitas, uji heteroskedestisitas, dan uji multikolinieritas. Yang kedua melakukan analisis regresi linier sederhana dan ketiga uji kelayakan model terdiri dari uji t dan uji koefisien determinasi $\left(R^{2}\right)$.

Menurut Sugiyono (2013) analisis regresi linier sederhana digunakan untuk memprediksi berapa jauh perubahan nilai variabel dependen, bila nilai variabel independen berubah-ubah atau naik turun. Persamaan regresi linier sederhana sebagai berikut:

$$
Y=a+b X+e
$$

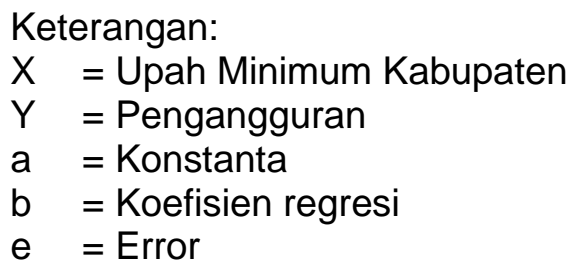

Hipotesis adalah jawaban sementara terhadap rumusan masalah dalam suatu penelitian. Berdasarkan teori di atas maka dirumuskan hipotesis penelitian sebagai berikut: 
$\mathrm{H}_{\mathrm{o}}$ : tidak terdapat pengaruh antara upah minimum kabupaten terhadap jumlah pengangguran di Kabupaten Bangka tahun 2007-2018.

$\mathrm{H}_{1}$ : terdapat pengaruh antara upah minimum kabupaten terhadap jumlah pengangguran di Kabupaten Bangka tahun 2007-2018.

\section{HASIL DAN PEMBAHASAN}

\section{Upah Minimum Kabupaten}

Menurut Peraturan Menteri Tenaga Kerja dan Transmigrasi Nomor 7 Tahun 2013, upah minimum kabupaten adalah upah minimum yang berlaku untuk seluruh kabupaten di satu provinsi.

Tabel 1. Upah Minimum Kabupaten Bangka tahun 2007-2018

\begin{tabular}{cc}
\hline Tahun & Upah (Rp) \\
\hline 2007 & 777.000 \\
2008 & 905.000 \\
2009 & 982.000 \\
2010 & 1.060 .000 \\
2011 & 1.322 .500 \\
2012 & 1.322 .500 \\
2013 & 1.622 .400 \\
2014 & 1.906 .000 \\
2015 & 2.100 .000 \\
2016 & 2.341 .500 \\
2017 & 2.534 .673 \\
2018 & 2.755 .443
\end{tabular}

Sumber: Badan Pusat Statistik Kabupaten Bangka, 2019.

Berdasarkan Tabel 1 dapat dilihat bahwa terjadi kenaikan Upah Minimum Kabupaten Bangka selama periode 12 tahun terakhir. Pada tahun 2007 upah minimum kabupaten Bangka sebesar 770.000 rupiah dan meningkat signifikan sebesar $257,85 \%$ pada tahun 2018 menjadi 2.755 .443 rupiah.

\section{Pengangguran}

Menurut Badan Pusat Statistik Kabupaten (2019) pengangguran meliputi penduduk yang sedang mencari pekerjaan, atau mempersiapkan suatu usaha, atau merasa tidak mungkin mendapatkan pekerjaan, atau sudah punya pekerjaan tetapi belum mulai bekerja. 
Tabel 2. Jumlah Pengangguran di Kabupaten Bangka tahun 2007-2018

\begin{tabular}{cc}
\hline Tahun & Pengangguran (jiwa) \\
\hline 2007 & 6.900 \\
2008 & 7.600 \\
2009 & 7.896 \\
2010 & 5.122 \\
2011 & 4.341 \\
2012 & 3.600 \\
2013 & 5.900 \\
2014 & 12.053 \\
2015 & 12.805 \\
2016 & 8.075 \\
2017 & 6.693 \\
2018 & 2.670 \\
\hline
\end{tabular}

Sumber: Badan Pusat Statistik Kabupaten Bangka, 2019.

Berdasarkan Tabel 2 dapat dilihat jumlah pengangguran di Kabupaten Bangka selama periode 12 tahun terakhir mengalami fluktuatif. Pada tahun 2007 jumlah pengangguran sebesar 6.900 ribu/jiwa, tingkat pengangguran tertinggi tahun 2015 sebesar 12.805 ribu/jiwa, dan pada tahun 2018 mengalami penurunan jumlah pengangguran sebesar $2.670 \mathrm{ribu} / \mathrm{jiwa}$.

\section{Uji Asumsi Klasik}

Analisis uji merupakan prasyarat dalam penelitian ini menggunakan uji asumsi klasik sebagai salah satu syarat dalam menggunakan analisis korelasi.

Setelah dilakukan uji asumsi klasik dari normalitas data berdistribusi normal, uji multikolenieritas data ini tidak terjadi multikolonieritas dan uji heteroskedastisitas tidak terjadi heteroskedastisitas, maka data ini memenuhi syarat untuk dilakukan uji regresi.

\section{Uji Regresi Sederhana}

Menurut Sugiyono (2013) analisis regresi linier sederhana digunakan untuk memprediksi berapa jauh perubahan nilai variabel dependen, bila nilai variabel independen berubah-ubah atau naik turun.

Tabel 3. Model Summary

\begin{tabular}{lll}
\hline Model & $\mathrm{R}$ & $\mathrm{R}$ Square \\
\hline 1 &, $076^{\mathrm{a}}$ &, 006 \\
a. Predictors: (Constant), Upah Minimum Kabupaten
\end{tabular}

Sumber: Data diolah, 2019.

Berdasarkan Tabel 3 dapat dilihat bahwa nilai koefisien korelasi $\mathrm{R}$ sebesar 0,076 dan $R$ Square atau koefisien determinasi sebesar 0,006. Dapat ditafsirkan bahwa upah minimum kabupaten memiliki pengaruh sebesar $0,6 \%$ terhadap 
pengangguran di kabupaten Bangka tahun 2007-2018 dan 99,4\% lainnya dipengaruhi oleh faktor-faktor lain di luar variabel upah minimum kabupaten.

Tabel 4. Koefisien

\begin{tabular}{ccccc}
\hline & Model & $\mathrm{B}$ & $\mathrm{t}$ & $\mathrm{Sig}$ \\
\hline 1 & (Constant) & 6407,031 & 2,553 &, 029 \\
& Upah Minimum &, 000 &, 242 &, 814 \\
a. Dependent Variable: Pengangguran & & &
\end{tabular}

Sumber: Data diolah, 2019.

Berdasarkan Tabel 4 dapat dilihat bahwa nilai konstanta 6407,031, sedangkan nilai UMK sebesar 0,000 , sehingga persamaan regresinya:

Pengangguran $=6407,031+0,00$ UMK

Menyatakan bahwa setiap penambahan $1 \%$ nilai UMK, maka nilai pengangguran tetap atau tidak bertambah. Koefisien regresi bernilai positif, sehingga dikatakan bahwa arah pengaruh variabel $X$ terhadap variabel $Y$ adalah positif. Berdasarkan nilai signifikan 0,814 >0,05, maka variabel $X$ tidak berpengaruh terhadap variabel $\mathrm{Y}$. Dilihat dari nilai $\mathrm{t}$ diketahui $\mathrm{t}$ hitung sebesar $0,242<\mathrm{t}$ tabel 2,228 , sehingga variabel upah minimum kabupaten tidak berpengaruh terhadap variabel pengangguran.

\section{Pengaruh Upah Minimum Kabupaten terhadap Pengangguran}

Berdasarkan nilai signifikan 0,814 $>0,05$, maka variabel $X$ tidak berpengaruh terhadap variabel Y. Upah minimum kabupaten tidak berpengaruh signifikan terhadap tingkat pengangguran di Kabupaten Bangka tahun 2007 - 2018. Kenaikan upah minimum kabupaten tidak berpengaruh terhadap pengangguran di Kabupaten Bangka disebabkan oleh masyarakat yang termasuk dalam angkatan kerja banyak bekerja dibidang informal, contohnya seperti bekerja di toko, dimana upah yang diterima sesuai dengan kehendak pemilik toko tersebut. Di Kabupaten Bangka juga masih banyak masyarakat yang bekerja sendiri dengan membuka usaha toko, bertani, melakukan tambang timah, dimana upah yang mereka terima tidak terpengaruh oleh upah minimum kabupaten yang ditetapkan pemerintah.

\section{KESIMPULAN}

Penelitian ini membuktikan upah minimum kabupaten tidak berpengaruh terhadap variabel pengangguran. Hal ini disebabkan oleh masyarakat, yang termasuk dalam angkatan kerja, banyak bekerja di bidang informal, contohnya seperti bekerja di toko, pembantu rumah tangga, tukang, dan pekerjaan sejenis. Dimana sektor ini memberi upah kepada pekerja sesuai dengan kehendak pemilik toko atau majikannya. Di Kabupaten Bangka juga masih banyak masyarakat yang bekerja sendiri dengan mendirikan usaha, bertani, melakukan tambang timah, dimana pendapatan yang mereka terima tidak terpengaruh oleh upah minimum kabupaten yang ditetapkan pemerintah. 
Berdasarkan hasil penelitian yang dilakukan, maka disarankan untuk penelitian selanjutnya bisa menambahkan variabel lain yang mempengaruhi pengangguran seperti PDRB, inflasi (Irewole, 2019), pendidikan, investasi (Suroso et al., 2016), dan kesempatan kerja (Zulkarnain, 2017). Penelitian selanjutnya disarankan menggunakan periode yang lebih panjang sehingga dapat memperoleh hasil yang representatif.

\section{DAFTAR PUSTAKA}

(1) Badan Pusat Statistik Kabupaten Bangka. (2019). Kabupaten Bangka Dalam Angka 2019. Badan Pusat Statistik Kabupaten Bangka. https://bangkakab.bps.go.id/publication/

(2) Hartanto, T.B. (2017). Analisis Pengaruh Jumlah Penduduk, Pendidikan, Upah Minimum dan Produk Domestik Regional Bruto (PDRB) Terhadap Jumlah Pengangguran di Kabupaten dan Kota Provinsi Jawa Timur Tahun 2010-2014. Jurnal IImu Ekonomi Terapan, 2(1). https://doi.org/10.20473/jiet.v2i1.5502

(3) Irewole, O.E. (2019). Inflation and Unemployment Relationship: A Dynamic Report of Nigeria And Mexico In the Perspective of Phillips Curve From 1991-2016. International Journal of New Economics and Social Sciences, 10(2), 11-30. https://doi.org/10.5604/01.3001.0013.8085

(4) Iwu, C.G., \& Opute, A.P. (2019). Eradicating Poverty and Unemployment: Narratives of Survivalist Entrepreneurs. Journal of Reviews on Global Economics, 8, 1438-1451. https://doi.org/10.6000/1929-7092.2019.08.127

(5) Mankiw, N. Gregory. (2007). Teori Makro Ekonomi Edisis Keenam. Erlangga.

(6) Nurcholis, M. (2014). Analisis Pengaruh Pertumbuhan Ekonomi, Upah minimum dan Indeks Pembangunan Manusia Terhadap Pengangguran di Provinsi Jawa Timur Tahun 2008-2014. Jurnal Ekonomi Pembangunan, 12(1), 45-57. https://doi.org/10.22219/jep.v12i1.3654

(7) Panjawa, J.L., \& Soebagiyo, D. (2014). Efek Peningkatan Upah Minimum terhadap Tingkat Pengangguran. Jurnal Ekonomi \& Studi Pembangunan, 15(1), 48-54. https://journal.umy.ac.id/index.php/esp/article/view/1283

(8) Sirait, N., \& Marhaeni, A.A.I.N. (2013). Analisis Beberapa Faktor Yang Berpengaruh Terhadap Jumlah Pengangguran Kabupaten/Kota di Provinsi Bali. E-Jurnal Ekonomi Pembangunan Universitas Udayana, 2(2), 108-118. https://ojs.unud.ac.id/index.php/eep/article/view/4299

(9) Sugiyono. (2013). Metode Penelitian Manajemen. Alfabeta.

(10) Sukirno, S. (2006). Makro Ekonomi Teori Pengantar. PT Raja Grafindo Persada.

(11) Suroso, A.I., Bakce, D., \& Firdaus, M. (2016). Impact of investment incentives on agribusiness and macroeconomy of Indonesia: A Computable General Equilibrium model. Journal of ISSAAS (International Society for Southeast Asian Agricultural Sciences), 22(1), 16-29.

(12) Zulkarnain. (2017). Study on Strengthening Economic Community Institutions in the Economy of MSME in Riau, Indonesia. International Journal of Economic Research, 14(2), 61-72. https://serialsjournals.com/abstract/51819 6.pdf 